\title{
スラブ・ユーラシア学の構築： \\ 開かれた地域研究へ
}

家田 修

\section{1. 社会主義研究から中域圈分析へ}

本COEが課題として設定したのは、従来のソ 連東欧社会主義研究を包括的なスラブ・ユーラ シア地域研究へと再構築することです。本 COE の中核組織である北海道大学スラブ研究センタ 一は、1990年代にリージョン研究及びサブ・リ ージョン研究に着手し、国際的な評価も得てき ましたが、今回の研究教育拠点形成プログラム ではリージョン研究を統合的・学際的に発展さ せるという企画をたてました。またこの拠点形 成に合わせて「中域圈Meso-area」という新し い空間分析概念を仮説として揭げ、国際的にそ の有効性を問うことを目指しました。というの は世界的にみて、旧ソ連東欧圈を全体としてど う分析するのかが大きな争点となっているから です。

従来、地域研究といえば地域の固有性を分析 するのが当然視されていましたが、いま地域は 地域統合や地球化（グローバリゼーション）な どの影響を受け、日々変容を遂げています。変 容する地域を動態として分析する空間的枠組み が中域圈です。つまり地域を固有性においてで はなく、可変的かつ重層的な地域アイデンティ ティをもつ空間としてとらえるというのが、中 域圈分析の基本的な考光方です。

旧ソ連東欧圈は中域圈分析に格好の素材を提 供しています。この巨大な地域はかつて社会主 義圈として単一の求心力をもっていましたが、
社会主義体制崩壊後、様々な地域統合や地域的 帰属意識の変容を経験し、現在はいくつもの特 色ある地域に分かれつつあります。地域ごとの 特色を生み出しているのは、まずはかつての求 心力の中心に位置するロシアとの関係ですが、 近年はエネルギー価格高騰を背景に強いロシア が急速に復活し、「ユーラシア・パワー」として 注目されています。ロシアの復活とその周辺地 域への影響は中域圈研究の最も重要な領域の一 つです。しかしそれに劣らず重要なのはスラ ブ・ユーラシア地域と西や東、ないしは南で隣 接する地域の動向です。例えば欧州統合という 要因を抜きにして旧東欧や旧ソ連西部地域は理 解できなくなっています。同様にスラブ・ユー ラシアの南部諸地域はイスラーム復興の強い影 響を受けています。またスラブ・ユーラシアの 東部は東アジア経済との結びつきを深めつつあ ります。

本COEではこうした大きな圈域で特色ある地 域を設定し、それぞれを東欧中域圈、中央ユー ラシア中域圈、シベリア・極東中域圈と名づけ、 おの打のと隣接する世界との関係を分析してき ました。つまりスラブ・ユーラシア研究はスラ ブ・ユーラシア地域それ自体の研究であると同 時に、隣接地域との関係が重要視されます。ま た研究が進展するにつれて、小規模な空間で中 域圈を設定することも、中域圈分析を進化させ るうえで有効であることが分かってきました。 例えば東欧全体の代わりにバルトを取り上げる、 
あるいは中央ユーラシア全体ではなく、南コー カサスやボルガ中流域に注目するという具合で す。それに合わせて隣接地域加らの影響も、例 えばイスラーム世界からの影響一般ではなく、 中東、イラン、あるいはトルコなど、きめ細か く識別することが必要になってきました。

もっとも中域圈分析は、地域を取り巻く様々 な外的影響の検討で終わるわけではありません。 それを通して地域アイデンティティを全体とし て描き出すことが究極の目標です。その際に中 心となるのは、複合的な外的要因を受け止める 主体形成の問題です。もちろん地域の主体をめ ぐっては、それをどのように定義するかで様々 な議論が戦わされてきました。中域圈では地域 主体の問題を特定の社会層やイデオロギーに結 びつけるのではなく、様々な隣接世界との位置 関係の中で形成される複合的アイデンティティ としてとらえようと考光ました。例えばウクラ イナの地域的自己認識を取り上げてみましょう。 ウクライナでは 2 年前に大統領選挙が行われ、親 西欧派のユーシチェンコが再選挙の末、選ばれ ました。欧米のマスコミはこれでウクライナが 親ロシア路線から親西欧路線へと転換するもの と期待しました。しかし現実にはロシアとEUの 間で「迷走」を続けているように見えます。し かしそれは迷走ではなく、ロシアとEUの架け橋 として自らを位置づけようとした結果です。か つてのソヴェト連邦ウクライナ共和国という位 置づけから、「東西の架け橋：ウクライナ」とい

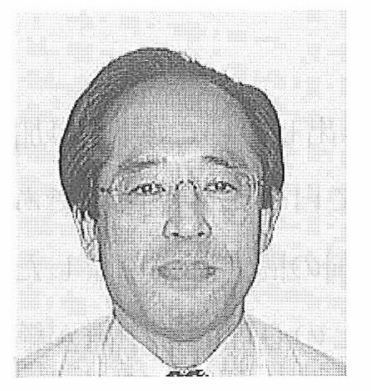

\section{PROFILE}

家田 修

(いえだ おさむ 1953年生) 北海道大学スラブ研究センター 教授

専門：地域研究

う新しい地域アイデンティティが形成されてい るのです。ウクライナはロシアとEUの対ウクラ イナ政策の間で、どう均衡を保ちながら自国の 舵取りをするのか、先の力学と舵取りの結果と してウクライナの地域的アイデンティティが生 まれているのです。親西欧派の大統領でさえこ のバランス感覚の中で政策決定を行わなければ なりません。つまり一方だけに帰属するわけに はいかない、あるいは両方に帰属しているとい う複合的な帰属意識がここに存在します。この 複合的な帰属意識を腑分けし、そして総合する のが中域圈研究の方法論です。

既にEU加盟を果たした東欧諸国についても同 様の地域的自己認識が見られます。この地域は 歴史を紐解いてみても、中世にはビザンッない しオスマン及び神聖ローマ帝国の影響下で地域 形成を行い、近現代には東のロシアと西のドイ ツなどからの統合作用を受けて地域秩序の再編 が行われました。そして今、「EU化」が進行し ていますが、現実にはEU内部での東西格差は解 消せず、ユーロ(共通通貨) 導入というEU統合 の象徴であり、統合の終着点でもある目標達成 はいまだ遠い先の話です。こうした「EU二流市 民」的立場は東欧の人々の間に、「東側隣人との 
一体感」さえ生み出しています。EU加盟前、東 側隣人にたいして自分たちは西側であるという 意識が新規加盟国の間で強まりましたが、加盟 後はかえって東との心理的な距離が縮まってい るのです。

ヨーロッパの東部は冷戦後の新しい国家形成 や地域統合の中で、単に国民的ないし民族的意 識を強化しただけでなく、消極的に表現すれば 「西と東のどちらでもない」ないし「どちらでも ある」というあいまいな地域意識、積極的に言 えば「中欧」意識ないし「東西の架け橋」という 空間的な自己認識を持つようになりました。こ うした複合的ないし重層的帰属意識を基に地域 の動態を考えるのが中域圈的な地域分析です。

このような地域分析方法は、急速な変貌を遂 げる旧ソ連東欧圈だけでなく、地域統合やグロ ーバル化の中で地域意識に変化が生じている世 界の諸地域に応用可能であると考えます。

\section{2.大学を超えた拠点形成}

本COEではスラブ研究センターを核として、 北海道大学内の文系全部局 (文学研究科、教育 学研究科、経済学研究科、法学研究科、言語文 化部、国際広報メディア研究科)を横断する事 業組織を創りましたが、事業推進者だけで閉じ た研究者集団を作ることが目的ではありません でした。目指したのは機能性と効率性に基づい て伸縮する開放的な研究者ネットワークの創造 です。そもそも北海道大学及び札晱圈の大学に
は広範なスラブ・ユーラシア関連の研究者がい ますし、かねてより北海道大学の文系部局やス ラブ研究センターは日本中のスラブ研究者の求 心力となってきました。一般に21世紀COEプロ グラムに打いては、大学内の組織改革が話題に 上りました。しかし本COEでは当初より大学の 枠を超えた全国の研究者ネットワーク形成を前 面に押し出し、研究でも若手育成でも、大学を 超えた拠点形成を追求しました。国際的な拠点 形成である以上、国内の第一線の研究者そして 次世代を担う若手研究者を全国的に紏合するこ とは自明のことです。文系に打ける研究拠点形 成では、特定の所属機関や特別な実験装置など に縛られる研究は例外的であり、いかにして効 率的で開放的なネットワークを創るかが拠点形 成の鍵だと考えます。私共の拠点概念は箱物で はなく、人と人の輪です。

次世代養成に限ってそうした成果を具体的に 紹介しますと、学内的に限定された事業は全学 共通大学院授業「スラブ・ユーラシア学」の開 講、及び大学院生への研究・学会発表支援だけ で、それ以外は全国公募型のプログラムばかり です。一つ目はCOE＝鈴川奨学生制度です。こ れはスラブ研究センターが1987年に始めた短期 招聘型の鈴川基金奨学生制度を発展させたもの です。すでに100名ほどの鈴川奨学生を世に送 り出した実績があり、「北大・鈴川」は日本にお ける若手スラブ研究者の登竜門となっています。 ただ鈴川基金は 90 年代末からゼ口金利状況に喘 いでいましたので、COEに採択されたのを機 
に、 $\mathrm{COE}=$ 鈴川基金として再出発させました。 これは日本のスラブ研究者を再生産する上で重 要な施策でした。実績としては、これまでの四 年間で通算51名の応募と 26 名の採用がありまし た。二つ目は公募型ポスドク研究員の雇用です。 従来、スラブ研究センターには旧COE研究員と 非常勤研究員の制度がありましたが、それは年 間に僅か一、名程度の採用枠でした。それが 21世紀COE予算により、現在では六名前後の COE研究員を雇用しています。これまでの五年 間で通算45名の応募があり、17名を採用しまし た。第三の全国型若手育成策は、博士論文を準 備中、ないし博士論文を執筆し終えたばかりの 大学院生をCOEのセミナーに積極的に招聘し、 研究報告と学際的評価の場を設定したことです。 通算で73名を招聘しました。第四の施策は国際 若手ワークショップです。これは国際シンポジ ウムに合わせて開催され、公募などで選ばれた 内外の若手研究者が英語で報告を行い、国際シ ンポジウム出席の研究者から批評を受けます。 こうした様々な支援策の結果、従来にも増して 若手研究者が大学の枠を超えて全国から北大に 集まるようになり、北大の理想的な研究環境 (専門的蔵書、学際的研究指導、国際的研究交 流、異なる大学で学んだ若い研究者同志の交流 など)の中で切硣环磨しています。

若手研究者にたいする求心力と共に、本 $\mathrm{COE}$ は海外の第一線の研究者をも強くひきつけてい ます。すなわちCOEの外国人招聘制度により、 世界で活躍する外国人研究者や現地の新進気鋭
の研究者を数ヶ月単位で招くことができるよう になり、単にシンポジウムのときだけでなく、 その前後の滞在などを通して、共同研究の実質 を高めることが可能になりました。五年間の公 募で通算 122 名の応募者があり、その中から 21 名を採用しました。

\section{冊子とウェッブによる成果発信}

北海道大学が国際的なスラブ研究の拠点として 評価されている理由に「発信力の強さ」がありま す。COE以前からスラブ研究センターは、時々 の研究動向を反映し、切り口が明確な国際シンポ ジウムを毎年二回開催してきました。COE開始 後の国際シンポジウムでは「スラブ・ユーラシア と世界経済」「「域圏と歴史」「「シベリア・極東 とアジア共同体」「スラブ・ユーラシアと隣接世 界」「中央ユーラシアとイスラーム」、「東欧中域 圈の政治と経済」、「中央ユーラシアの地域的・超 域的ダイナミズム：帝国、イスラーム、政治」、 「21世紀のシベリア・極東 : アジア共同体のパー トナー」、「帝国を超えて：ユーラシア文化のコン テクストに拈けるロシアのイメージ」などのテー マが取り上げられました。定期シンポジウムの他 にも世界スラブ学会理事会との共催シンポジウム 「スラブ・ユーラシア研究はどこへゆくのか」(札 幌、2004年)、あるいは12力国50名以上の研究者 と専門家が参加した「東欧における地位法シンド ローム」ブダペスト会議（2004年）といった不定 期の国際会議も開催しました。こうしたシンポジ 
ウムなどで発表された論文及び共同研究や連携研 究の主要な成果をとりまとめ、独自の欧文研究シ リーズSlavic Eurasian Studiesを刊行していま す。このシリーズは冊子体として全世界の主要図 書館（約500）に送付され、さらに北大のウェッ ブ上でも常時閲覧可能です。Slavic Eurasian Studiesの一冊一冊はシリーズとしての連続性を 保ちながら、個別にも独立した価值を持つように 工夫しています。内容はもちろん、体裁も専門の デザイナーが担当し、市販の単行本に勝るとも劣 らない装丁になっています。非売品にもかかわら ず、国際的な学術雑誌で書評される例も少なく なく、海外からしばしば購入希望の申し込みを 受けます。本シリーズはこれまで15冊が刊行さ れ、最終的には20冊程度を予定しています。残 念ながら、政府補助金による成果報告のため販 売できませんが、将来は市販可能なシリーズへ と発展させたいと考えています。和文での成果出 版では、北海道大学が民間の出版社と共同出 版契約を結ぶという新方式を打ち出し、「スラ ブ・ユーラシア叢書」及び「スラブ・ユーラシア 学講座」を順次刊行しています。ともあれ、以上 のような「発信力の強さ」はスラブ研究センター のホームページに対するアクセス数に如実に現 れ、月間 $30 \sim 40$ 万件にのぼり、そのうち半数以 上が海外からです。

\section{地域研究コンソーシアム}

2004 年 4 月に地域研究コンソーシアムが50近
くの関連組織の参加を得て結成されました。三 年を経た現在、加盟組織数は70ほどにまで達し ました。ここには全国の主要な地域研究組織、 地域研究の大学院組織、地域研究学会そして世 界の諸地域で活動する社会団体が名を連ねてい ます。その詳細については地域研究コンソーシ アムのホームページをご覧ください (www.jcas.jp)。立ち上げ以来、短期間でこの ように大きな関心を惹きつけたのは、箱として の研究所や研究センターないし大学院研究科が その機能を十分に果たすためには、組織を超え た横の連携を強めることが不可欠であると考え ているからです。コンソーシアムは組織を単位 とする広範な研究者ないし専門家のネットワー クであり、ここでも拠点とネットワークの相互 に補う関係が生まれています。本COEもこのコ ンソーシアムの一員であり、他にも地域研究関 連のCOEが幾つも加盟しています。今日、世界 の地域は地域を超えて互いに強く影響を及ぼし 合いながら変容を遂げています。地域を超えた 大きな統合の動き、あるいはグローバル化を地 域の視点から分析するためにも、伝統的な地域 の枠にこだわらないコンソーシアムのような幅 広いネットワークが重要な触媒的役割を果たし てくれるものと期待されます。

中域圈分析では柔軟で開放的な地域概念の構 築が目指されましたが、地域研究の研究教育組 織のあり方に扎いても開放性がもっとも重要な 指針であると考えます。 